\title{
INTERFERENCIA DE LA BRUCELLA ABORTUS CEPA 19 EN EL DIAGNÓSTICO DE LA BRUCELOSIS POR INOCULACIÓN ACCIDENTAL MEDIANTE JERINGAS IN- ADECUADAMENTE HIGIENIZADAS
}

\author{
AguirRe, N. ${ }^{1}$; Lugaresi, C. ${ }^{2}$; Mondino, M. ${ }^{1}$; ZenKLUssen, A. ${ }^{3}$; \\ VANZINI, V. ${ }^{1}$ \& TORIONI DE ECHAIDE, $S .{ }^{1}$
}

\section{RESUMEN}

Se analizó la interferencia en el diagnóstico serológico de brucelosis en vacas, luego de utilizar jeringas multidosis contaminadas con Brucella abortus C19, para vacunar contra rinotraqueítis infecciosa bovina - diarrea viral bovina (RIB-DVB). Se vacunaron 20 vacas distribuidas equitativamente en cinco grupos, utilizando jeringas con distintos tratamientos: escurridas o lavadas con agua, ambas mantenidas a temperatura ambiente 7 días (G1 y G2), o utilizadas inmediatamente (G3 y G4), respectivamente. Para el grupo control (G5), se usó una jeringa estéril. En los G1 a G4 se observaron reacciones positivas a Brucella en BPA, ELISA indirecto en suero y leche, ELISA de competición, fijación del complemento y polarización fluorescente, desde el día 7 pos-vacunación (pv). Se detectó la extinción gradual de los anticuerpos y hacia el día 112 pv todavía se detectaba al menos una vaca positiva en las diferentes pruebas. El G5 resultó negativo. Se aconseja administrar la vacuna contra brucelosis con jeringas exclusivas o estériles desechables.

Palabras clave: Brucella abortus, brucelosis bovina, respuesta inmune humoral, pruebas serológicas.

\section{SUMMARY}

\section{Interference with brucellosis diagnostic tests caused by syringes contaminated with Brucella abortus S19.}

To evaluate the feasible interference of residual Brucella antigen inoculated to adult cattle in the serological diagnosis of bovine brucellosis, B. abortus S19 contaminated syringes were used to inoculate IBR and BVD vaccines. Twenty Holstein cows randomly distributed into 5 study groups (G) were inoculated using syringes differently treated. Syringes were drained or washed with water and used after 7 days at room temperature for G1 and G2, or used immediately for G3 and G4, respectively. Cattle of group G5 were inoculated with sterile syringes. After 7 days post-vaccination, serological positive reactions were observed in cattle from G1 to G4 using BPA, indirect ELISA (serum and milk samples), competitive ELISA, complement fixation and fluorescent polarization assay. The level of antibodies decreased gradually and after 112 days post-inoculation 1 cow from each group remained as positive to the different tests. It is advisable to use exclusive or disposable syringes to inoculate Brucella S19 vaccine.

Key words: Brucella abortus, bovine brucellosis, humoral immune response, serological tests.

1.- INTA, EEA Rafaela. C. C. 22. (2300) Rafaela, provincia de Santa Fe. Email: naguirre@rafaela.inta.gov.ar 2.- Actividad privada. (2820) Gualeguaychú, provincia de Entre Ríos.

3.- Actividad privada. Avda. Los Colonizadores S/N. (2301) Villa San José, provincia de Santa Fe. Manuscrito recibido el 15 de julio de 2009 y aceptado para su publicación el 2 de octubre de 2009. 